Кристијан Векоњ

Филолошки факултет

Универзитет у Београду $811.111^{\prime} 276.6$

$811.163 .41 ' 276.6$

https://doi.org/10.18485/filkult.2016.2.ch10

\title{
ДРУГО ИМЕ ЗА КРАЈ
}

\section{Сажетак}

Прелиставајући странице историје може се приметити како се, свакога пута када се човек сусретне са нечим што је веће од њега (ратови, природне и људски створене катаклизме,...), неизбежно појављују пророци Судњег дана који позивају на обраћење и указују на то како је човек заслужио горки крај. Човека, поред вечитог страха од смрти, прати и страх од свршетка света. Језици (као носиоци људске културе) садрже мноштво термина који именују ову појаву. Овај рад истражује терминологију која се користи у енглеском и српском језику, а везана је за „културу апокалипсе“.

Кључне речи: апокалипса, терминологија, српски језик, енглески језик

Тешко је тачно одредити која реч у неком језику има највише синонима због некада ситних а некада већих нијанси у значењу. На основу различитих истраживања, дошло се до закључка како су појмови који имају највише синонима у енглеском језику речи које се свакодневно употребљавају попут придева good, bad, happy, beautiful; глагола везаних за говор - speak/tell или именица попут book или love. Интересантно је да је реч са највише забележених синонима у енглеском језику придев drunk. Бенџамин Френклин је још давне 1735. године сачинио Drinker's Dictionary са 228 појмова, међу којима се налази велик број синонима ове речи. Лексикограф Пол Диксон је 1983. године поставио рекорд када је сакупио 2660 израза везаних за пијаност, а 2006. године је издао књигу Drunk: the Definitive Drinker's Dictionary у којој се налази чак 2964 израза, укључујући и огроман број синонима за пијаност. 
Када би се упоређивале листе речи са највише синонима у различитим језицима, засигурно би се на њима нашао знатан број истих речи - оних које су везане за свакодневни говор, попут горепоменутих речи из енглеског језика. Такође је сигурно да би се на свакој листи нашле и неке речи које су специфичне за живот у поднебљу у коме се дати језик говори. Узмимо на пример Ескиме, код којих би се на листи речи са највише синонима високо котирала реч снег, јер они познају око педесет различитих израза везаних за ову природну појаву.

Оно што би још могло да буде заједничко већини језика јесте велик број различитих речи и израза везаних за табуисане термине (за које се често користе и еуфемизми). Овде се под термином „табуисано" не мисли само на оне данашње непристојне и вулгарне речи, већ, пре свега, на оно што је од давнина било табу тема за људско друштво - болест и смрт.

Прелиставајући странице историје може се приметити како се, свакога пута када се човек сусретне са нечим што је веће од њега (ратови, природне и људски створене катаклизме,...), неизбежно појављују пророци Судњег дана који позивају на обраћење и указују на то како је човек заслужио горки крај. Од свог првог сусрета са смрћу некога од њему блиских људи, човек је свестан како његов пут на овом свету води ка личном свршетку. Иако је смрт неминовна, њу прати вечити страх, страх од непознатог - да ли је смрт коначна или је само прелаз у неко друго стање. Страх од смрти је повезан и са још једним страхом - страхом од краја света.

Постоји много теорија о свршетку света. Све веће светске религије предвиђају коначни суд при чему ће, након многих знакова времена, страдања и патње, Бог доћи на земљу и са собом у рај повести добре људе, а лоше послати у пакао. Након Другог светског рата многи предвиђају да ће нуклеарна катастрофа уништити Земљу. Цунамији, земљотреси, вулкани, поплаве, вируси и остале природне појаве такође прете, показујући како човек више није најјача карика на овој нашој Плавој планети и како ће кад-тад, зарад постизања некаквог еквилибријума, морати да наступи уништење човечанства. А и човек сам прети себи - новим технолошким открићима, уплитањем у природне токове,... Није чудно што се данас човечанство све чешће пита да ли су му дани одбројани. 
У енглеском и српском језику могу се наћи многи изрази који су везани за смак света. Најопштији изрази везани за крај света у енглеском језику су: the end of the world (у преводу на српски: крај света, смак света, пропаст света) и end of days / last day / last days (последњи дан(и)) . Остали изрази би се грубо могли поделити на две групе једну у којој се налазе изрази са религијским конотацијама, и другу, у којој се налазе речи које говоре о било каквој врсти уништења.

Изрази са библијским конотацијама:

\begin{tabular}{|c|c|c|}
\hline $\begin{array}{c}\text { Изрази на енглеском } \\
\text { језику }\end{array}$ & Значење & $\begin{array}{c}\text { Најчешћи преводи } \\
\text { на српски језик }\end{array}$ \\
\hline apocalypse & 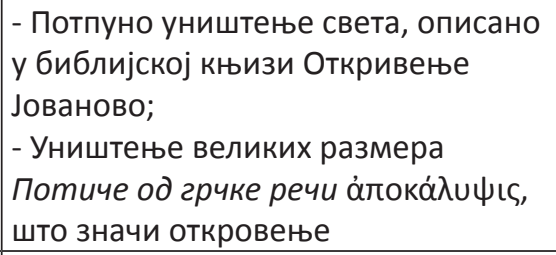 & $\begin{array}{l}\text { Апокалипса } \\
\text { Синоними: објава, } \\
\text { откровење, визија, } \\
\text { виђење }\end{array}$ \\
\hline $\begin{array}{l}\text { Armageddon } \\
\text { Синоними: } \\
\text { Final battle, } \\
\text { Final battleground, } \\
\text { Showdown between } \\
\text { good and evil }\end{array}$ & $\begin{array}{l}\text { - Према Новом завету, коначна } \\
\text { битка између добра и зла уочи } \\
\text { судњег дана (Отк. 16:16 - И сабра } \\
\text { их на место које се јеврејски зове } \\
\text { Армагедон) } \\
\text { - Катастрофа која може довести до } \\
\text { уништења човечанства } \\
\text { Потиче из хебрејског језика од har } \\
\text { mӗgiddōn, umо значи брдо Мегидо }\end{array}$ & $\begin{array}{l}\text { Армагедон } \\
\text { Синоними: } \\
\text { Последња битка, } \\
\text { Коначна битка } \\
\text { између добра и зла }\end{array}$ \\
\hline $\begin{array}{l}\text { Judgment day } \\
\text { Синоними: } \\
\text { Day of Judgment, } \\
\text { Last Judgment, } \\
\text { the Judgment, } \\
\text { Day of reckoning, } \\
\text { Day of doom, } \\
\text { Doomsday }\end{array}$ & $\begin{array}{l}\text { - Дан када човек буде морао да } \\
\text { одговара за своје грешке и лоша } \\
\text { дела, } \\
\text { - Последњи дан постојања света, } \\
\text { крај света }\end{array}$ & $\begin{array}{l}\text { Судњи дан } \\
\text { Синоними: } \\
\text { Страшни суд, } \\
\text { Дан обрачуна }\end{array}$ \\
\hline
\end{tabular}

Постоје и изрази из скандинавске и германске митологије који су познати и користе се у англофоној књижевности: 


\begin{tabular}{|l|l|l|}
\hline \multicolumn{1}{|c|}{ Изрази } & \multicolumn{1}{|c|}{ Значење } & $\begin{array}{l}\text { Најчешћи преводи } \\
\text { на српски језик }\end{array}$ \\
\hline Ragnarök & $\begin{array}{l}\text { - Коначна борба између богова и } \\
\text { сила зла у којој ће умрети и богови } \\
\text { и смртници, а свет ће бити уништен } \\
\text { (скандинавска митологија) }\end{array}$ & $\begin{array}{l}\text { Рагнарок, } \\
\text { Последња битка, } \\
\text { Сумрак богова }\end{array}$ \\
\hline $\begin{array}{l}\text { Götterdämmerung } \\
\text { Twilight of the Gods }\end{array}$ & $\begin{array}{l}\text { - Суноврат богова (германска } \\
\text { митологија) }\end{array}$ & Сумрак богова \\
\hline
\end{tabular}

Изрази везани за уништење:

\begin{tabular}{|c|c|c|}
\hline $\begin{array}{c}\text { Изрази на } \\
\text { енглеском } \\
\text { језику }\end{array}$ & Значење & $\begin{array}{c}\text { Најчешћи преводи } \\
\text { на српски језик }\end{array}$ \\
\hline annihilation & $\begin{array}{l}\text { - Потпуно уништење } \\
\text { - Претварање материје у енергију } \\
\text { (физика) }\end{array}$ & $\begin{array}{l}\text { анулирање, } \\
\text { поништење, } \\
\text { ништење, } \\
\text { сатирање }\end{array}$ \\
\hline carnage & - Убијање великог броја људи & $\begin{array}{l}\text { покољ, } \\
\text { масакр, } \\
\text { клање } \\
\end{array}$ \\
\hline cataclysm & 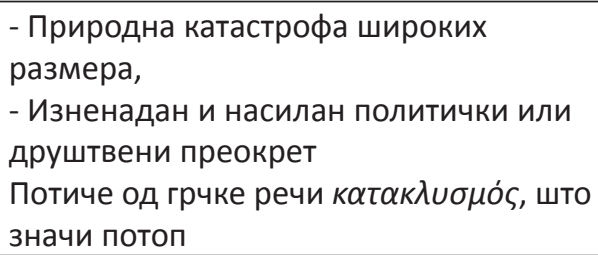 & катаклизма \\
\hline catastrophe & $\begin{array}{l}\text { - Догађај који доводи до велике и } \\
\text { изненадне штете и патње } \\
\text { Потиче од грчке речи катабтрофи́, што } \\
\text { значи преокрет, револуција }\end{array}$ & катастрофа \\
\hline decimation & $\begin{array}{l}\text { - Масовно убијање или уништење } \\
\text { одређене врсте или групе, } \\
\text { - убијање сваког десетог као казна } \\
\text { (историја) }\end{array}$ & десетковање \\
\hline devastation & $\begin{array}{l}\text { - Уништавање или оштећење великих } \\
\text { размера }\end{array}$ & $\begin{array}{l}\text { пустошење, } \\
\text { разарање, } \\
\text { девастација }\end{array}$ \\
\hline downfall & $\begin{array}{l}\text { - Губитак моћи, просперитета или } \\
\text { статуса } \\
\text { - Пропаст }\end{array}$ & $\begin{array}{l}\text { пропаст, суноврат, } \\
\text { крах }\end{array}$ \\
\hline
\end{tabular}


Филологија културе

\begin{tabular}{|l|l|l|}
\hline eradication & $\begin{array}{l}\text { - Потпуно уништење нечега, уклањање } \\
\text { сваког трага о постојању нечега }\end{array}$ & $\begin{array}{l}\text { искорењивање, } \\
\text { истребљење }\end{array}$ \\
\hline extermination & $\begin{array}{l}\text { - Убијање, нарочито целе групе људи } \\
\text { или животиња; ликвидација } \\
\text { - Тотално уништење }\end{array}$ & $\begin{array}{l}\text { истребљење, } \\
\text { искорењивање, } \\
\text { уништење }\end{array}$ \\
\hline holocaust & $\begin{array}{l}\text { - Масовно уништење или убијање, } \\
\text { изазвано ватром или нуклеарним ратом } \\
\text { Потиче од грчке речи одлокачбтоц,цтоло } \\
\text { значи спаљен }\end{array}$ & $\begin{array}{l}\text { холокауст, } \\
\text { пустошење ватром }\end{array}$ \\
\hline obliteration & $\begin{array}{l}\text { Потпуно уништење, брисање } \\
\text { quietus }\end{array}$ & $\begin{array}{l}\text { брисање, } \\
\text { предавање } \\
\text { забораву, } \\
\text { поништавање }\end{array}$ \\
\hline - Смрт, напуштање света живих, & $\begin{array}{l}\text { смирење, } \\
\text { смрт }\end{array}$ \\
\hline
\end{tabular}

У речницима који су издати на територији Србије (и бивших држава у оквиру којих се некада налазила) могу да се нађу и следећи термини који се везују за крај света:

Смак = свршетак, крај, пропаст

Кијамет (турцизам) = судњи дан, смак света, пропаст, несрећа, непогода, невреме

Кљук = „потпуна пропаст људи или стоке, кад се све на неки начин сатре у гомили, једно преко другога као да су кљукнути у јаму да се не зна ко је ко и шта је шта“ (Лалевић 638)

Морија = куга, помор, епидемија

Анализирајући све ове изразе може се извући једно - да претпостављени крај не оставља никакву дозу оптимизма. Било да буде изазван божанским силама или силама природе или вођен људским насиљем и људском глупошћу, резултат смака света ће бити исти - човечанство ће нестати, а и сама Земља (уколико не буде уништена) ће бити разорена и опустошена. Роџер Зелазни је у једном свом роману написао: „Не будите ме због смака света, осим ако су одлични специјални ефекти“. Судећи по предвиђањима и овим изразима... биће то прави спектакл! 


\title{
Литература
}

Библија. https://wwwyu.com/biblija/. Web.

Бидерман, Ханс. Речник симбола. Београд: Плато, 2004. Принт.

Гербран, Ален и Шевалије, Жан. Речник симбола. Нови Сад: Stylos Art, 2013. Принт. Ђосић, Павле (и сарадници). Речник синонима. Београд: Корнет, 2008. Принт.

Ерић, Љубомир. Речник страха. Београд: Архипелаг, 2007. Принт.

Лалевић С, Миодраг. Синоними и сродне речи српскохрватскога језика. Београд:

Свезнање, 1974. Принт.

Longman Dictionary of Contemporary English. Harlow: Longman, 2009. Print.

Лујак, Тамара (уред.). Речник страха. Младеновац: Пресинг, 2014. Принт.

Милинковић, Александар. Лексикон митова и легенди старог и новог света.

Београд: Беокњига, 2004. Принт.

Oxford Living Dictionaries. https://en.oxforddictionaries.com. Web.

Речник српскохрватскога књижевног језика. Нови Сад и Загреб: Матица српска и Матица хрватска, 1967. Принт.

Cambridge Advanced Learner's Dictionary. Cambridge: Cambridge University Press, 2008. Print.

\author{
Kristijan Vekonj \\ Faculty of Philology \\ University of Belgrade
}

\section{A DIFFERENT NAME FOR THE END}

\section{Summary}

The pages of human history show that the doomsday prophets appear every time the humanity encounters something that is bigger than it (wars, natural and man-made cataclysms...). They call for conversion from sin and suggest how the mankind deserves the bitter end. Besides the perpetual fear of death, humanity is burdened with the fear of the end of the world. Languages (as bearers of human culture) contain many terms for this phenomenon. This paper explores the terminology used in the English and Serbian language that is related to the "culture of apocalypse".

Key Words: apocalypse, terminology, Serbian language, English language 